\title{
What Do We Mean by 'Forgiveness?': Some Answers from the Ancient Greeks
}

\author{
Maria Magoula Adamos and Julia B. Griffin
}

\begin{abstract}
There seems to be confusion and disagreement among scholars about the meaning of interpersonal forgiveness. In this essay we shall venture to clarify the meaning of forgiveness by examining various literary works. In particular, we shall discuss instances of forgiveness from Homer's The Iliad, Euripides' Hippolytus, and Aristotle's Nicomachean Ethics and we shall focus on the changes that the concept of forgiveness has gone through throughout the centuries, in the hope of being able to understand, and therefore, of being able to use more accurately, contemporary notions of forgiveness. We shall also explore the relationship between forgiveness and concepts that are closely associated with it, such as anger/resentment, hurt, clemency, desert/merit, excuse, etc.
\end{abstract}

Key Words: Syngnome, aphesis, Iliad, Hippolytus, Aristotle.

$* * * * *$

With forgiveness, as with so much else, the thought of the Ancient Greeks provides a basis for Western thinking - a basis and a wealth of paradigms. We will start our exploration here with the Ancient Greek concept of 'syngnome.' 'Syngnome' derives from the verb 'syngignoskein,' which literally means 'being of the same opinion,' or 'having a common understanding." 'Syngnome' is primarily a cognitive term that implies one is able to adopt the other's point of view.

\section{The Iliad, Book XXIV $\left(8^{\text {th }}\right.$ Century BCE)}

In Book XXIV of the Iliad there is no mention of forgiveness, yet when we study carefully its details, we will recognise not only that it occurs, but also that it plays a major role in the understanding of this particular book. The central, and perhaps most moving scene of the book, and arguably of the whole Iliad, is the meeting between the aged Priam, the king of Troy, whose brave son Hector, the best Trojan warrior, was killed on the battlefield by Achilles, the best Greek warrior. Achilles has killed Hector in order to avenge the death of his dear friend Patroclus. In his attempt to alleviate his pain and his sense of loss, Achilles has been abusing the body of Hector by tying it behind his chariot and dragging it around Patroclus' tomb. He keeps doing this endlessly, aimlessly. It is as if Achilles wants to replace his uncontrollable grief with anger and revenge by abusing the dead body of his beloved friend's killer. Yet, it is clear that Achilles' 
pain is so deep that even this horrific abuse of Hector's body is incapable of providing any real relief.

It is important to note that this meeting between Priam and Achilles did not take place out of either man's sheer 'free will.' It was ordained by Zeus, the father of gods. ${ }^{2}$ When Priam meets Achilles in the latter's tent, he introduces himself with an act of supplication and asks Achilles to honour the gods and remember his own aged father. ${ }^{3}$ He begs Achilles to take pity upon him:

Honour then the gods, Achilles, and take pity upon me remembering your father, yet I am still more pitiful;

I have gone through what no other mortal on earth has gone through;

I put my lips to the hands of the man who has killed my children. ${ }^{4}$

Achilles cannot help but be moved by Priam's words. Both men cry remembering the awfulness of war and the losses that each had suffered. In the end, Achilles gives back Hector's body, and receives Priam's ransom.

The question emerging here is the following: Is this a scene of 'forgiveness,' ('syngnome')? We would like to argue that yes, it is. Surely, it is a peculiar sense of 'syngnome' where the two mortals are 'compelled,' so to speak, by a god to come together, and no one asks for forgiveness or apologises for the horrors each had caused (directly or indirectly) the other. Yet, does not Achilles offer 'syngnome' to Priam, when he allows him to stay in his tent? Is it not a 'syngnome' when Achilles orders an elaborate dinner in order to sit and eat with Priam, the father of his beloved friend's killer, even though he had just eaten? ${ }^{5}$ Likewise, is it not an act of 'syngnome' when Priam goes as a suppliant to his son's killer's tent? By seeing each other's humanity and common lot they are both able to empathise with one another and have an understanding. By remembering his own father, Achilles realises that Priam is very much like a father, who is also regal, beautiful and respectful. Priam realises that Achilles is not simply a killing monster, as Hecuba, his wife had claimed Achilles to be. He is also beautiful and worthy of respect. In a way, one gets the notion that if it were not for this awful war, both he and Priam might have been friends. War is the only one to blame.

\section{Forgiveness in Euripides' Hippolytus $\left(5^{\text {th }}\right.$ Century BCE)}

In Euripides' Hippolytus there is also a similar 'command' by a god for an 'understanding,' or 'syngnome,' but this time the wrongdoer himself asks for forgiveness and the wronged party willingly grants it. The two mortals involved this time are Hippolytus and his father Theseus. Theseus, not realising that his wife, Phaedra, lied when she accused his son, and her stepson, Hippolytus of defiling their bed, curses Hippolytus to destruction. The curse is inevitably 
realized, as it is a gift from the god Poseidon, and Hippolytus finds a tragic death when his chariot horses panic and flee, dragging him over the rocks of Trozen. Despite Hippolytus' protestations, Theseus, still hurting from the death of his dear wife, is determined not to listen or believe his son. Only when the goddess Artemis reveals the truth to Theseus, does he understand the gravity of his offence: he killed not only an innocent person, but his dear son. While Hippolytus is on his deathbed, Theseus asks desperately for forgiveness, which Hippolytus grants. Hippolytus is the only mortal in the play who actively forgives, and Theseus is the only mortal who is forgiven. The gods do not forgive despite the old slave's pleading with Aphrodite to forgive Hippolytus because 'gods ought to be wiser than mortals.'

This instance of forgiveness in Hippolytus is both similar and different to the one discussed in the Iliad. In both scenes there are two mortals who have a common understanding, and a realisation of their common humanity and mortal nature. In both works the gods will that a common understanding or forgiveness occurs. But in addition, in Hippolytus, the two mortals Theseus and Hippolytus 'forgive' each other because Artemis' revelation showed that they were both ignorant and constrained by the higher power of a god: Aphrodite.

Given that every mortal character in the play is guilty, it is easy to see that each is also concerned with 'forgiveness,' 'pardon' and 'excusal. ${ }^{\prime 6}$ However, we see that in the last scene the word used by Euripides is not only 'syngnome,' but also 'aphiemi' meaning 'to absolve or discharge.' The word occurs when Theseus asks in 1450 'do you 'aphies' (i.e. 'discharge,' or 'absolve') me of bloodguiltiness?' The use of the word 'aphiemi' is significant. It indicates that in order for 'syngnome' to occur, there must be a discharge of the horrible crime by the wronged party. Given that the word 'aphesis' will later be used primarily to mean Christian forgiveness, the use of a similar word in Hippolytus is of great significance. We begin to see here how the concept of Greek 'forgiveness' ('syngnome') is being 'enriched' so to speak, and ultimately changed, by the addition of closely-related concepts, i.e., 'aphesis,' 'eleutheros phonou,' (freeing from pain) etc.

\section{3. 'Syngnome' in Aristotle's Nicomachean Ethics ( $4^{\text {th }}$ Century BCE)}

Aristotle uses the concept of 'syngnome' mainly in Books III and VII, when he talks about voluntary actions and akrasia, or weakness of the will, respectively. In Book III 1110a24 he tells us that there is 'syngnome' when a person's acts are either due to ignorance of the relevant information, or due to extreme force that no human would endure. Aristotle points out that what makes an action involuntary, and thus forgivable, is ignorance of the particular circumstances. (In other words, one cannot claim that one is ignorant of the universals, such as 'drinking and driving is wrong.' However, if an agent, unbeknownst to her, was given a drink that was alcoholic and drove under the influence, she will be committing an 
involuntary act, and as such, she is both forgiveness- or pardon-worthy.) It is curious that Aristotle, who wrote in the $4^{\text {th }}$ Century BCE, and several years after Euripides, is here using not only the words 'syngnome' but also 'eleos' to signify 'excuse,' 'pity' and 'pardon.' The word 'eleos' will also be used later by Christianity to signify a closely-related concept of forgiveness: pity, mercy, pardon and compassion. So, now we see that the concept of 'forgiveness' is going through a transformation: it does not simply refer to strict cognition and common understanding, or shared point of view; it now includes sharing of emotion, such as pity and compassion.

In Book $\mathrm{V}$ Aristotle is again talking about involuntary actions and tells us in 1136a that some are forgiveness-worthy, whereas others are not. All wrongdoings that are due to ignorance and done in ignorance are 'syngnomika.' For instance, if I am late to a meeting because, due to a glitch in my computer, I did not receive the latest email with the relevant information, then I am both late in ignorance and due to ignorance. However, involuntary actions which are done in ignorance, but are due to ignorance because of some kind of passion, are to be blamed and thus are not forgivable or 'syngnomonika.' For instance, if I hit a pedestrian because I am drunk and do not know what I am doing, then my action, although done in ignorance, is not excusable or forgivable, because the ignorance is due to my passion of 'drinking excessively.'

In Book VII, 1149b1-5 Aristotle discusses akrasia, and why some akratic actions are forgiveness-worthy. Akrasia due to 'one's spirited nature, or 'thumos,' is forgivable because it is capable of listening to reason, and is thus less shameful. However akrasia due to 'epithumia,' i.e., desire, is incapable of listening to reason and thus, is unforgivable. The reason given for this is that it is more forgivenessworthy to follow natural desires that are common to all.

Several scholars, including Griswold, have wondered why Aristotle does not praise forgiveness as one of the virtues. ${ }^{7}$ Griswold's view is that the answer lies in Aristotle's perfectionist conception of Ethics. That is, the virtuous person, like a true 'megalopsuchos,' would be perfect, and therefore would already have all the virtues/excellences, and consequently would never do something that requires forgiveness. We, on the other hand, wish to argue that although it is true that Aristotle saw the virtues as excellences of character, he did not praise forgiveness because he thought that justice and its fellow virtues are much more important for an ethical theory. Indeed, without justice human life would be impossible and unbearable. Yet, without forgiveness, life is still possible. In other words, justice is a necessity, while 'forgiveness' is a contingent 'good.'

This perhaps helps us understand why the gods in Ancient Greek literature, are not forgiving towards humans. For instance, we see in Hippolytus that although Artemis orders humans to forgive, she herself does not. Additionally, Aphrodite is intent on punishing the wrongdoer and she is deaf to the pleading words of Hippolytus' servant to be forgiving! We believe that the reason for this is that for 
the gods the most important virtue is justice and the attribution of order. The gods would like to instill in humans the idea that they [humans] could and ought to be just like themselves [the gods]. This type of justice allows for 'syngnome' in cases where the agent is not responsible for the wrong action. However, they would not allow for a system of Ethics built on forgiveness where agents are both responsible for the wrong action, and culpable. For such Ethics faces the danger of sidestepping 'justice' in favour of 'forgiveness,' as it is less onerous to do the wrong thing and then be forgiven, than striving to always be excellent and just.

So, Aristotle and earlier Greek writers do not praise forgiveness as a virtue, not simply because the virtuous individual is too perfect to do something wrong, and thus he or she does not need forgiveness; rather Aristotle thinks that justice and the other practical virtues are more important to serve as a foundation in his ethical system than forgiveness.

If space permitted, we would indicate here the way that these ancient ideas of forgiveness are reflected, altered, and enlarged upon in much later literary works: notably Shakespeare's Cymbeline, (early $17^{\text {th }}$ century), which, when viewed from this perspective, offers an extraordinary range of forgiveness, some of it easily achieved; some like that of Achilles or Hippolytus, hard sought. But that must be the subject for another chapter.

\section{Notes}

${ }^{1}$ Jacqueline de Romilly in Indulgence et Pardon dans la Tragédie Grecque (Paris: Les Belles Lettres, 1995), 62-77, also argues that 'syngignoskein' relies on intelligence, while the Latin 'ignoscere' relies on the opposite, implying one's not wanting to know, or choosing not to know: 'Greek pardon relies on intelligence: This is the root meaning of 'syngignoskein,' by contrast with the Latin 'ignoscere,' 'to pardon,' which literally means 'to choose not to know.' While the Latin says 'I do not want to know' (or I forget,) the Greek responds 'I understand' [je comprends], (p. 64).

${ }^{2}$ Homer, The Iliad, trans. Robert Fagles (New York: Viking Penguin, 591), Book 24, lines 105-120.

${ }^{3}$ Homer, 602: Book 24, lines 485.

${ }^{4}$ Ibid., lines 503-504.

${ }^{5}$ Here is how Homer describes the scene (Homer, 609: Book 24, lines 739-44):

when they had put aside desire for food and drink, Priam the son of Dardanus gazed at Achilles, marveling now at the man's beauty, his magnificent build face-to-face he seemed a deathless god ... and Achilles gazed and marveled at Dardan Priam, beholding at his noble looks, listening to his words. 
${ }^{6}$ See P. Vellacott's excellent discussion regarding 'forgiveness' in Hippolytus in his Euripides' Alcestis and Other Plays (Harmondsworth: Penguin, rev. ed. 1974), 22-23.

${ }^{7}$ See Charles L. Griswold, Forgiveness: A Philosophical Exploration (Cambridge: Cambridge University Press, 2007), 7-9.

\section{Bibliography}

Aristotle. 'Nicomachean Ethics'. In The Complete Works of Aristotle: The Revised Oxford Translation, edited by Jonathan Barnes, Vol. 2, 1729-1867. Princeton, NJ: Princeton University Press, 1994.

De Romilly, Jaqueline. Indulgence et Pardon Dans la Tragédie Grecque. Paris: Les Belles Lettres, 1995.

Euripides. 'Hippolytus'. In Euripides' Alcestis and Other Plays. Edited by Philip Vellacott. Harmondsworth: Penguin, 1974.

Griswold, Charles. Forgiveness: A Philosophical Exploration. Cambridge: Cambridge University Press, 2007.

Homer. The Iliad. Translated by Robert Fagles. New York: Viking Penguin, 1998.

Kosman, Aryeh. 'Being Properly Affected'. In Articles on Aristotle's Ethics, edited by Amelie O. Rorty, 103-116. Berkeley, CA: University of California Press, 1980.

Nussbaum, Martha G. Therapy of Desire. Princeton, NJ: Princeton University Press, 1994.

Maria Magoula Adamos is an Associate Professor of Philosophy in the Department of Literature and Philosophy at Georgia Southern University. Her main research interest is in Philosophy of Emotions, Ancient Philosophy (Aristotle,) and more recently, in forgiveness.

Julia B. Griffin is an Associate Professor of English in the Department of Literature and Philosophy at Georgia Southern University. She has a BA in Classics and Dphil in Renaissance English Literature, which she now teaches. 